\title{
Brucellosis should also be kept in mind on chronic meningitidis
}

\section{Kronik menenjit etyolojisinde bruselloz da akılda bulundurulmalıdır}

\author{
ürkçe Kısa Başlık: Kronik menenjit etyolojisi
}

Short Title: Chronic meningitis etiology

Kağan Şevik, Melahat Yılmaz, Merve Büyükçelik, Murat Ergün, Fusun Zeynep Akcam

Süleyman Demirel Üniversitesi Tıp Fakültesi, Enfeksiyon Hastalıkları ve Klinik Mikrobiyoloji Ana Bilim Dalı, Isparta, Türkiy

\section{Corresponding Author Information}

Fusun Zeynep Akcam

fusunzeynepakcam@gmail.com

05325641780

https://orcid.org/0000-0002-8691-035X

30.12 .2020

03.01 .2022

Keywords: Chronic meningitis, bruselloz, tüberküloz

Anahtar Kelimeler: Kronik menenjit, bruselloz, tüberküloz

Sayın Editör,

Derginizde yayınlanan "Tüberküloz menenjiti tanılı iki olgu” başlıklı yazıyı ilgiyle okuduk (1). Dünya Sağlık

Örgütü verilerine göre her y1l 10 milyon kişi tüberküloz hastalığına yakalanmakta ve 1,5 milyon insan

tüberküloz nedeniyle hayatını kaybetmektedir (2). Ülkemizde tüberküloz sıklığı ise geçmiş yıllara kıyasla azalmıș olmakla birlikte halen daha dünya tüberküloz yükünün $\% 85$ 'ini sağlayan on sekiz öncelikli ülkeden biri durumundayız (2). Santral sinir sistemi tüberkülozu, tüberküloz olguları içerisinde nadir görülmesine rağmen mortalite ve morbiditesi dolayısıyla çok önemlidir. Söz konusu makalede yazarlar, ülkemiz açısından çok önemli bir infeksiyon hastalığı olan tüberküloza ve tüberküloz menenjitin tanı zorluklarına dikkat çekmiş Lancet uzlaşı tanı kriterlerini tanıtmışlardır. İlgiyle okuyup faydalandığımız bu makaledeki paylaşılan olgular özelinde, kronik menenjit ile ilgili iki konuya dikkat çekmek istiyoruz.

Birincisi, her iki olguda da dörtlü antitüberküloz tedavi başlandığı belirtilmiş ancak kortikosteroid tedavisinden bahsedilmemiştir. İnfeksiyöz menenjitlerin tedavisinde steroid kullanımı hep tartışılagelmiş olmakla birlikte tüberküloz menenjitinde bazal eksüdanın ve varsa tüberkülomların rezolüsyonunu sağladığından dolayı önerilmektedir (3). Yazarlar tarafından olguların klinik evrelemesi belirtilmemiştir. Anlatılan klinik bulguları ile biz, olguları evre II olarak değerlendirdik. Tüberküloz menenjitinde özellikle evre II ve III de $60-80 \mathrm{mg} / \mathrm{gün}$ prednizon tedavisi önerilmektedir $(3,4)$. İkinci konu ise her iki hastanın da brusella infeksiyonu açısından tetkik edilmesi gerekliliğidir. Sunulan birinci olgunun hikâyesinde hayvancılık öyküsü de bulunduğundan, hastalık etyolojisinde mutlaka brusellozun araştırılması gerektiğini düşündük. Uzun süre ile yavaş ve dalgalı seyirli bir klinik tablo olarak tanımlan kronik menenjitlerin etyolojisinde nörobruselloz önemli bir yer tutmaktadır (4). Ülkemizde bruselloz yaygın olarak görüldüğünden her iki olgunun da kan ve BOS örneklerinden brusella aglütinasyonu çalışılması gerektiğini düşündük. İkinci olguda M.tuberculosis üremiş olduğundan tüberküloz menenjit tanısı kesindir. Ancak ilk olguda nörobruselloz ekarte edilememiş görünmektedir.

Nörobruselloz, brusellozun en önemli klinik tablolarından biri olup hastalarda morbiditenin azaltılması, erken tanı ve uygun tedavi ile mümkündür (5). Kronik menenjit etyolojisinde, özellikle endemik bölgelerde akla gelmelidir.

Kaynaklar:

1. Kösehasanoğulları G, Yüce A, İdilman F. Tüberküloz menenjiti tanılı iki olgu. Turk J Neurol 2012; 18(1): 26-29

2. https://www.who.int/health-topics/tuberculosis\#tab=tab_1 (Ulaşım: 28 Aralık 2020) 
3. Fitzgerald DW, Sterling TR, Haas DW. Mycobacterium tuberculosis. In: Mandell GL, Bennett JE, Dolin R (eds). Principles and Practise of Infectious Diseases. 7.bask1. Philadelphia: Churchill Livingstone, 2010: 3129-3163

4. Baldwin KJ, Zunt JR. Evaluation and Treatment of Chronic meningitis. Neurohospitalist. 2014, 4(4):185-195.

5. Akçam FZ, Akçam M, Yılmaz M, Nurlu Temel E, Kaya O, Yılmaz GR. Nörobruselloz: iki olgu, iki farklı prezentasyon. Turk J Neurol 2020; 26(4): 342-345

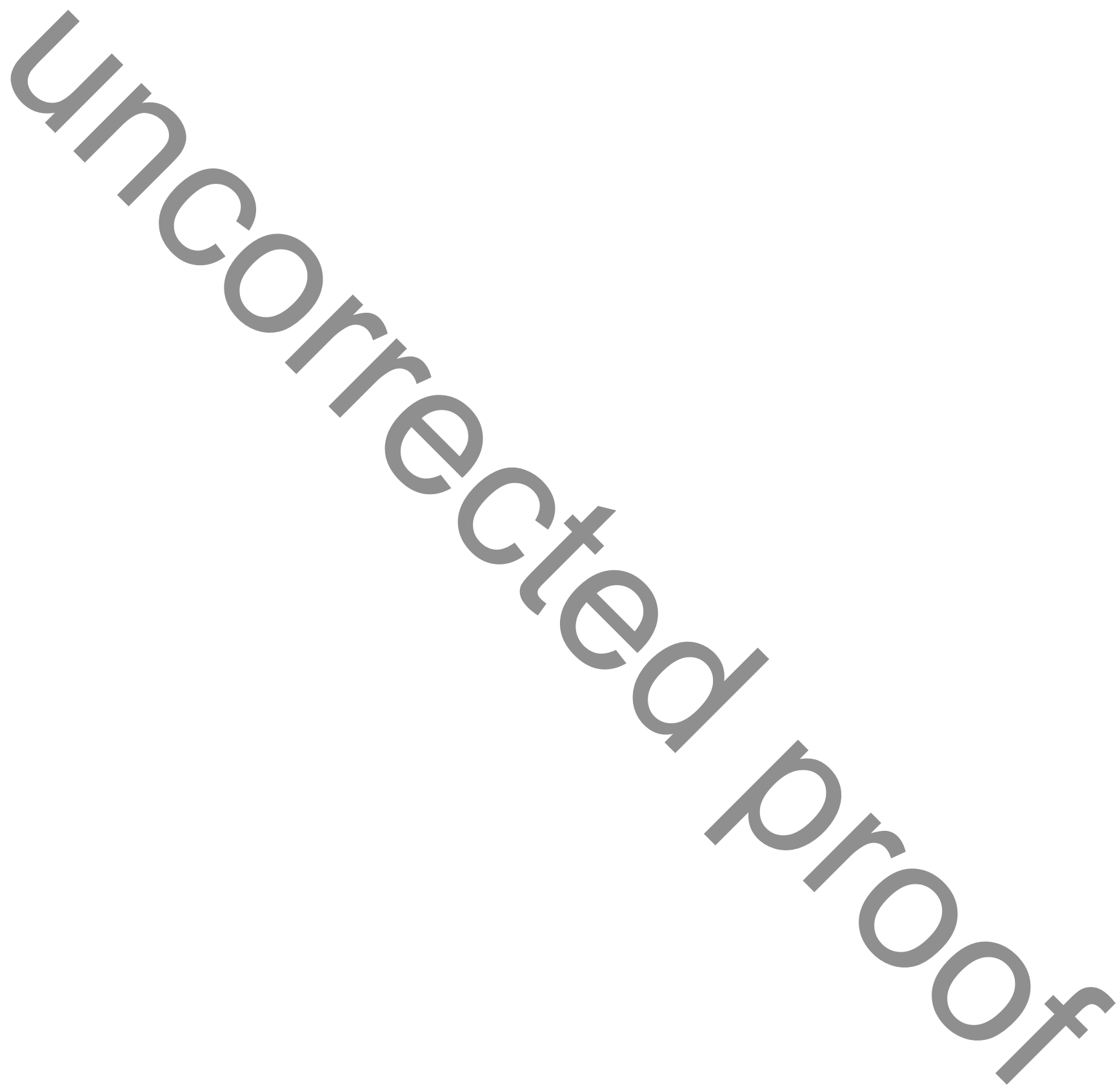

